\title{
The role of workers' perceptions towards the uncertain result of ergonomic program
}

\author{
Anizar Anizar ${ }^{a}$, Abdul Rahim Matondang ${ }^{\mathrm{a}}$, Rizabuana Ismail ${ }^{\mathrm{a}}$ and Nazaruddin Matondanga
}

${ }^{a}$ Universitas Sumatera Utara, Medan, Indonesia

\begin{tabular}{l}
\hline C H R O N I C L E \\
\hline Article history: \\
Received February 28, 2021 \\
Received in revised format May \\
20,2021 \\
Accepted June 32021 \\
Available online \\
June 72021 \\
\hline Keywords: \\
Program result uncertainty \\
Ergonomic program \\
Workers' perception
\end{tabular}

\section{Introduction}

The palm oil industry is a strategic sector in Indonesia, which contributes approximately 3.5 percent to the Gross Domestic Product (GDP). Many people depend on their livelihoods in the palm oil industry to improve their family welfare - this is in line with the priority in achieving Sustainable Development Goals (SDGs 2030; Muda et al., 2018 \& Purba 2019). In Indonesia, most Palm oil mills use semi-automatic machines and workers only supervise the production process. However, there is still some manual material handling performed by workers, such as sorting fresh fruit bunches. Workers also assist in the process at the boiling station by manually opening the sterilizer door and then attaching a rope to the lorry filled with boiled fresh fruit bunches and pulling them out. Inappropriate manual material handling will cause mild to severe pain complaints (Simoneau et al., 1996). One way to solve the pain complaints problem is by implementing an ergonomic program that is supported by all workers (Bernardes et al., 2012). The ergonomic program can be implemented as changing machines, changing work methods, increasing workforce, or increasing rest time. Its application must be integrated at the organizational level by involving all parties and performed sustainably (De Jong \& Vink, 2002; Tullar et al., 2010; van Eerd et al., 2010; Jahangiri et al., 2015; Rasmussen et al., 2017; Muda et al., 2020). Successfully implementing an ergonomic program will reduce complaints of worker pain and thus improve their life quality. The uncertainty of successfully implementing an ergonomic program makes active participation from workers a prerequisite (Zalk, 2001; Loisel et al., 2001). However, workers' active participation only happens if they have a positive attitude and beliefs in the expected behavior. Meanwhile, all this time the implementation of the ergonomic program solely focuses on the physical aspects of the work environment without considering the worker's attitudes (Whysall et al., 2004). Workers' perception regarding the ergonomic program implemented will affect their decision about rejecting or accepting it. In this case, the workers' perception can be further * Corresponding author

E-mail address: anizar usu@usu.ac.id (A. Anizar)

(c) 2021 Growing Science Ltd. All rights reserved. doi: $10.5267 /$ j.uscm.2021.6.004

\begin{abstract}
Manual activities of workers in palm oil factories cause pain complaints that can be resolved with an ergonomic program. However, the uncertainty of the success of the ergonomic program requires active involvement from workers. This study aims to discuss the role of workers'
perceptions towards the success of the ergonomic program intervention in palm oil mills. By referring to the theory of reasoned action and technology acceptance model, acceptance of workers to ergonomics programs are influenced by perceived usefulness, perceived ease of use,
and perceived trust. All these research variables were analyzed simultaneously using Partial Least Squares Structural Equation Modeling (PLS-SEM) software, in which data were obtained
from questionnaires given to 280 people working in 20 palm oil mills in North Sumatra Province. The sampling method used is simple random sampling and model estimation is performed using
PLS regression algorithm and resampling bootstrapping method. The result shows that perceived usefulness has the biggest effect on the success of the ergonomic program, followed by perceived
trust and perceived ease of use, which has a smaller effect. This study focuses on workers' perception that needs to be considered for facing uncertain results in implementing an ergonomic program.
\end{abstract}


divided into perceived usefulness, perceived ease of use, and perceived trust that will affect their intention (Ramos et al., 2018; Saeed Al-Maroof et al., 2020). Perceived usefulness is defined as the extent to which workers believe that using a particular system will improve performance. Perceived ease of use is defined as the extent to which workers believe that the implemented system will be easy to use (requiring less effort) and the technology applied will be easily understood (Davis, 1989). Meanwhile, perceived trust is the level of workers' trust in the success and benefits that will be obtained from the implementation of technology. However, it is necessary to have a match between the problems found and the changes to be made (Skoglind-öhman, 2004). This will affect workers' trust that the ideas and solutions developed will indeed solve the problems they face at work.

Previous studies on the success of ergonomics programs from the perspective of workers' perceptions towards technology acceptance have never been discussed. More precisely, to date, there is no study about workers' perception towards acceptance of technology in palm oil mills, hence whether workers accept the intervention is still unclear. Thus, understanding the workers' perception of their willingness to be involved and implement the ergonomic program is crucial. Based on this condition, some studies are needed to determine how big the role of workers' perceptions is and which perceptions affect the success of the ergonomic program the most. Hence, this research will provide solutions to increase the success of the ergonomic program implemented in palm oil mills.

\section{Literature Review}

\subsection{Uncertainty of successfully implementing the ergonomic program}

The ergonomic program is implementing technology in organizational systems, which requires workers as end-users to be actively involved. The ergonomic program has the concept of continuous improvement and decision-making based on the results of joint discussions. Thus, in addition to management commitment, there are few more crucial aspects: work relations, good communication, and active employee involvement (Burgess-Limerick, 2018). The success of the ergonomic program is highly dependent on the cooperative involvement of management and workers; therefore, the dynamics of workers and management groups are important. Employee involvement and good communication with management will lead to effective implementation of the ergonomic program (Dale, et al., 2018). However, the success of an ergonomic program is uncertain, as to how to involve large numbers of workers and to find why workers are willing to participate are still questionable (Dixon \& Theberge, 2011). Implementing a program in an organization requires workers' understanding of the changes that will occur (Austin \& Claassen, 2008). Consequently, the readiness of workers to accept changes is decisive for the success of the program.

\subsection{Reason Action Theory}

Reason action theory (TRA) states that a person's behavior is based on voluntary behavior and his/her behavior depends on intention. This intention is influenced by subjective attitudes and norms (Fishbein \& Ajzen, 1975). Attitudes will affect a person's behavior both positively and negatively. However, if attitudes are not followed by behavior, then the behavior is influenced by subjective norms. Subjective norms contribute to whether a person will perform the behavior and refer to a person's perceptions regarding other people's opinions of the behavior he will do.

\subsection{Technology Acceptance Model}

Technology acceptance model 3 (TAM3) is a strong framework to determine user acceptance of a certain technology (Davis \& Venkatesh, 1996). There is a causal relation between beliefs about technology benefits, ease of use, and the behavior that results from it. An early indication of user acceptance is important, since applying technology will have enormous implications for the sustainability of the organization. Perceived usefulness, perceived ease of use, and perceived trust are factors that play a role in technology acceptance behavior (Davis, 1989; Ghazizadeh, et al., 2012; Choi \& Ji, 2015, Muda et al., 2019).

\subsection{Perceptions of Workers}

This study uses TRA and TAM3 as their basis to explain that workers' perceptions influence the success of the ergonomic program (Ajzen \& Madden, 1986; Venkatesh \& Bala, 2008). TRA aims to understand the voluntary behavior of workers who carry out a behavior based on the results to be obtained. This is in line with TAM3, which states that there is a causal relation between workers' perceptions of the technology being applied in the ergonomic program and the action that occurs. It means that it is possible to predict the willingness of workers to be involved in ergonomic programs before the implementation of the technology. Thus, we assume that workers' perceptions of the ergonomic program will increase the likelihood of an action being performed. When workers believe in the benefits of a soon-to-be-applied technology, they will be willing to use it.

\section{Methods}

This type of research is a correlation study aiming to analyze the various factors influencing the success of the ergonomic program. Correlation analysis is used to determine whether there exists a relationship between variables. This study uses a quantitative approach in collecting and analyzing data and uses a questionnaire as a data collection tool. Participants in this 
study are workers on the production floor of the palm oil mill, from the loading ramp station to the kernel station. Participants represent workers from the 3 work shifts that exist in each palm oil mill. The population of this study is workers at 20 palm oil mills in North Sumatra Province. The palm oil mill population is obtained from the website of the Ministry of Industry of the Republic of Indonesia for the commodity type of palm oil (Kementerian Perindustrian RI, 2015). Simple random sampling is chosen as the sampling method, to ensure each element of the population has the same chance of being selected. The exogenous construct is the perception of workers, namely perceived usefulness (X1), perceived ease of use (X2), and perceived trust (X3). The endogenous construct is ergonomic program success (Y). The questionnaire used a five-point Likert scale ranging from strongly disagree (1) to strongly agree (5). The researcher explained the objectives of the study and the relevant ergonomics terms to the participants. The questionnaire used in this study has constructs that are adapted from previous studies. Perceived Usefulness is measured by indicators of punctuality and results accuracy, which consists of four questions (Baker-Eveleth \& Stone, 2015). Perceived Ease of Use is measured by indicators of convenience and suitability, which consists of three questions (Dachyar \& Banjarnahor, 2017). Perceived Trust is measured by indicators of experience and satisfaction, which consists of three questions (McKnight et al., 2002). Ergonomic program success is measured by indicators of work safety, work comfort, work quality, and productivity, which consists of 4 questions (Wee et al., 2014; Kalkis \& Roja, 2016). Partial Least Squares Structural Equation Modeling (PLS-SEM) with WarpPLS3.0 software was used to analyze the variables of this study simultaneously (Hair et al., 2014). Next was simultaneously performing a measurement model test and structural model test. Measurement model tests will prove the validity and reliability of constructs through convergent validity and discriminant validity.

\section{Results and Discussion}

\subsection{Participant Characteristics}

There are 280 people who participate in this study and all participants are male (100\%). Characteristics of the participants are presented in Fig. 1 - most of the participants have a high school education background (75\%) and some are still educated below (11\%). Approximately $44 \%$ of participants have worked for more than 10 years, $23 \%$ of them have worked for $5-10$ years, and $19 \%$ of them have only worked for $1-2$ years.

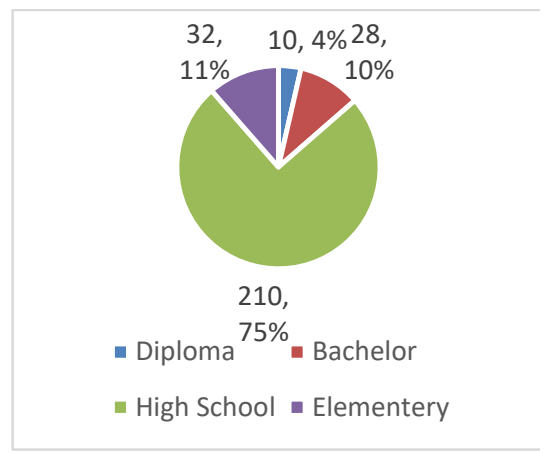

Education

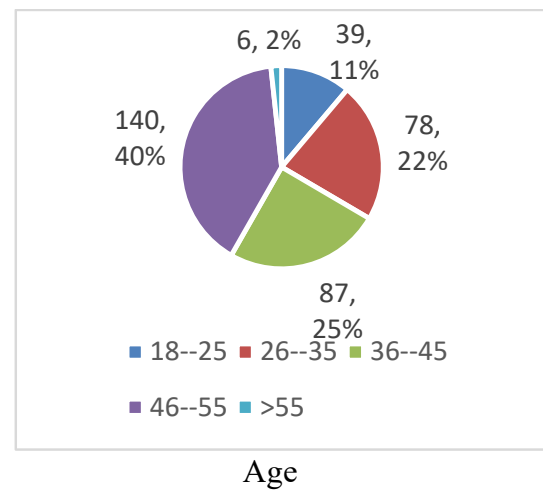

Fig. 1. Characteristics of the participant

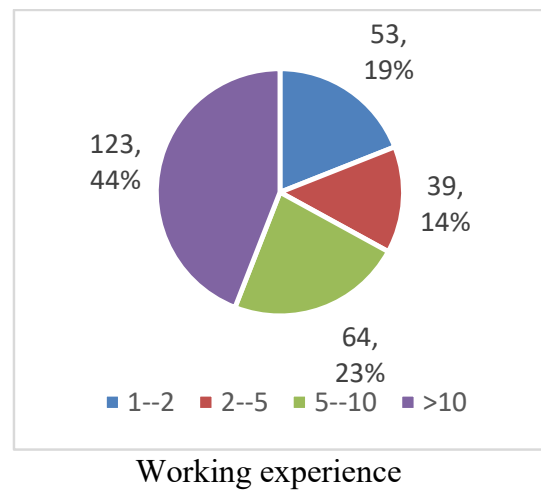

Working experience

\subsubsection{Convergent Validity}

The measurement model's convergent validity test measurement model is based on the factor loading value of the indicator. Perceived usefulness, perceived ease of use, perceived trust, and ergonomic program success are reflective constructs, so their loading values must be greater than 0.7 and their p-significant value must be less than 0.05 (Hair et al., 2014). The loading factor value of each construct indicator satisfies the validity and reliability requirements as listed in Table 1.

Table 1

Convergent Validity

\begin{tabular}{|c|c|c|c|c|}
\hline Constructs & Perceived Usefulness & Perceived Ease of Use & Perceived Trust & Ergonomic Program Success \\
\hline pul & 0.922 & & & \\
\hline pu2 & 0.868 & & & \\
\hline pu3 & 0.912 & & & \\
\hline pu4 & 0.906 & & & \\
\hline peoul & & 0.939 & & \\
\hline peou2 & & 0.933 & & \\
\hline peou3 & & 0.891 & & \\
\hline tst1 & & & 0.856 & \\
\hline tst2 & & & 0.904 & \\
\hline tst3 & & & 0.881 & \\
\hline ergol & & & & 0.918 \\
\hline ergo2 & & & & 0.881 \\
\hline ergo 3 & & & & 0.918 \\
\hline ergo 4 & & & & 0.913 \\
\hline
\end{tabular}




\subsubsection{Discriminant Validity}

The discriminant validity test using the Fornell-Larcker approach shows that the square root of AVE is higher than the correlation between other latent variables. Table 3 shows that the discriminant validity of the perceived usefulness construct is 0.902 greater than $0.505,0.471,0.543$, and 0.566 . Likewise, the discriminant validity for perceived ease of use, perceived trust means that the condition for discriminant validity is met.

Table 2

Discriminant Validity

\begin{tabular}{|c|c|c|c|c|}
\hline Constructs & Perceived Usefulness & Perceived Ease of Use & Perceived Trust & Ergonomic Program Success \\
\hline Perceived Usefulness & $(0.902)$ & & & \\
\hline Perceived Ease of Use & 0.505 & $(0.921)$ & & \\
\hline Perceived Trust & 0.471 & 0.493 & $(0.880)$ & \\
\hline Ergonomic Program Success & 0.566 & 0.598 & 0.565 & $(0.908)$ \\
\hline
\end{tabular}

Ergonomic Program Success

\subsubsection{Reliability Test Result}

The reliability of the research instruments was tested using Composite Reliability (CR) and Cronbach Alpha (CA) as shown in Table 3. The result of CR and CA tests shows that all values are reliable since all of them are about 0.7.

Table 3

Reliability Test Results

\begin{tabular}{llll}
\hline Constructs & Indicators & Cronbach's Alpha $(\alpha)$ & Composite Reliability (CR) \\
\hline Perceived Usefulness & pu & 0.814 & 0.946 \\
Perceived Ease of Use & peou & 0.911 & 0.944 \\
Perceived Trust & tst & 0.855 & 0.912 \\
Ergonomic Program Success & ergo & 0.929 & 0.949 \\
\hline Source: SmartPLS Result $(2021)$ & & & \\
\hline
\end{tabular}

Source: SmartPLS Result (2021).

\subsubsection{Explained Variance $\left(R^{2}\right)$ and Prediction Relevance $\left(Q^{2}\right)$}

The R-squared value to predict the effect of perceived usefulness, perceived ease of use, and perceived trust simultaneously on the success of the ergonomic program is shown in Table 4. Perceived usefulness, perceived ease of use, and perceived trust together can influence the success of the ergonomic program by $55.3 \%$. The remaining percentage is influenced by other variables not studied here. There is also a $\mathrm{Q}^{2}$ value on the success of the ergonomic program of $0.564>0$, meaning that the observed value is properly reconstructed, hence the model has predictive relevance.

Table 4

Explained Variance $\left(\mathrm{R}^{2}\right)$ and Prediction Relevance $\left(\mathrm{Q}^{2}\right)$ Test

\begin{tabular}{lll} 
& Explained Variance $\left(\mathrm{R}^{2}\right)$ & Prediction $\mathrm{Relevance}\left(\mathrm{Q}^{2}\right)$ \\
\hline Ergonomic Program Success & 0.553 & 0.564 \\
\hline Source: SmartPLS Result (2021). & &
\end{tabular}

\subsubsection{Hypotheses Testing Results}

The theoretical correlation between exogenous construct and endogenous construct was tested using path analysis. The significance of the direct effect of perceived usefulness, perceived ease of use, and perceived trust on the success of the ergonomic program are shown in Table 5. The result of hypothesis testing shows that all three perceptions significantly support the success of the ergonomic program.

\section{Table 5}

Result of Hypothesis Testing

\begin{tabular}{lll}
\hline & Path coefficient & P-value \\
\hline Perceived usefulness $\rightarrow$ ergonomic program success & 0.208 & $0.002^{*}$ \\
Perceived ease of use $\rightarrow$ ergonomic program success & 0.168 & $0.008^{*}$ \\
Perceived trust $\rightarrow$ ergonomic program success & 0.180 & Yes $^{*}$ \\
\hline
\end{tabular}

Perceived trust $\rightarrow$ ergonomic program success

Note: ${ }^{*}$ Significant at $\mathrm{p}<0.05$.

The coefficient value of each variable is shown in Fig. 2 and shows that perceived usefulness, perceived ease of use, and perceived trust influence the success of the ergonomic program. In comparison, perceived usefulness has the greatest influence among these three perceptions. The increase in perceived usefulness has a direct effect on the success of the ergonomic program by $20.8 \%$. This result is supported by a previous study which states that perceived usefulness affects attitudes more than perceived ease of use and perceived trust (Renny et al., 2013). 


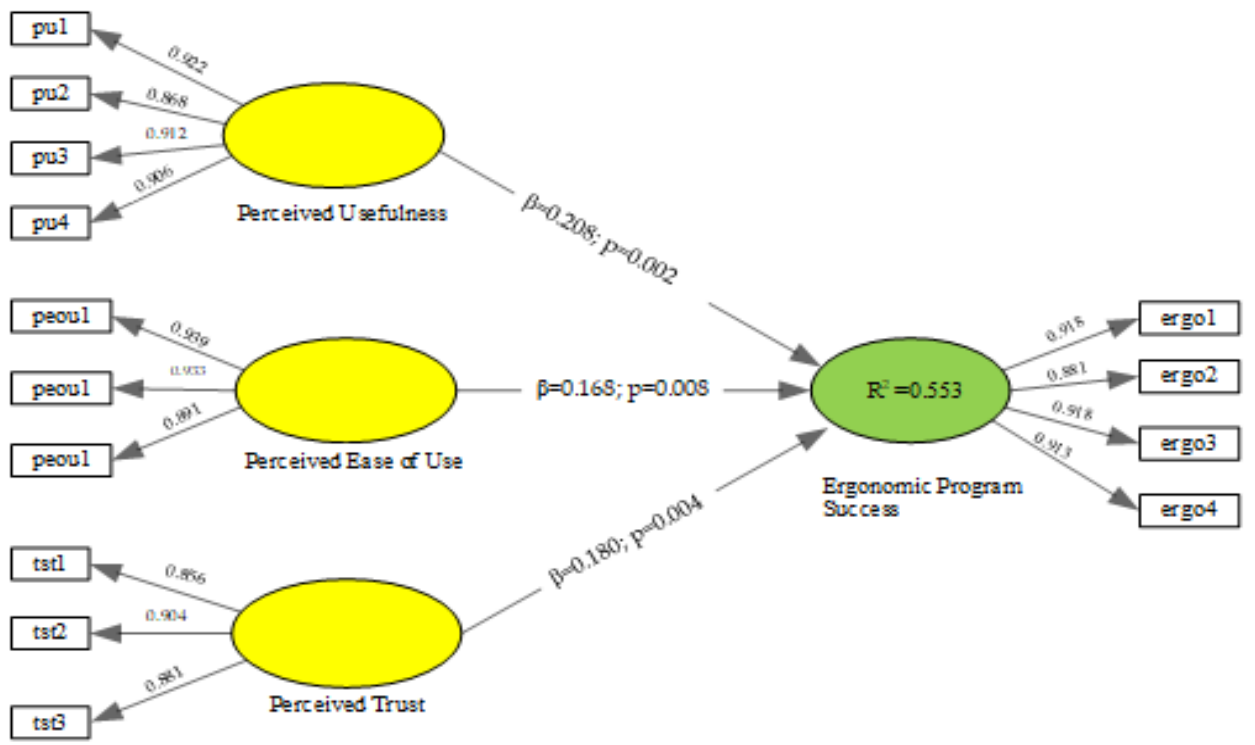

Fig. 2. Full Research Model

\section{Discussion}

This study explores the influence of workers' perceptions namely perceived usefulness, perceived ease of use, and perceived trust on the success of the ergonomic program in palm oil mills. Ergonomic program is a complex process, as it aims to improve work conditions in palm oil mills, thus affecting the life quality of the workers. Comprehensive implementation of an ergonomic program accompanied by proper monitoring will achieve the desired results. So far, the ergonomic program tends to focus on physical changes and work processes, even though workers are one of the critical success factors (van Eerd et al., 2010). Because workers are an organization's most asset, optimizing workers' actions will improve organization performance (Muda et al., 2018). Therefore, many aspects need to be considered properly before making any change to the system, work processes, work procedures, and work facilities used. Successfully implementing the ergonomic program in palm oil mills will improve workers' performance, since they can work painlessly and more comfortably. Workers will develop their perception during the adoption process, a time when workers can interact with the ergonomic program offered. During this time, they can evaluate initial perceptions, which may change their perceptions altogether and cause intention changes. If the workers perceive that the new technology introduced in this program will benefit themselves, they will be willing to get involved. Workers' involvement is crucial to the success of the program because workers are the ones who understand all processes on the production floor best. Of the three perceptions, it is the perceived usefulness that dominates the success of the ergonomic program since workers can feel the impact of their work directly. The impact is workers can work more quickly and comfortably, provide better results, and have less noticeable pain complaints. The next is perceived trust - workers who believe in the benefits of the ergonomic program in palm oil mills will cause a worker to be actively involved.

Perceived trust is strongly influenced by workers' experience, i.e. ergonomic program done previously. Workers will be willing to implement the program, follow the stated schedule and rules, share their experiences, coordinate in workgroups, etc. Such active participation from workers will contribute to the success of the ergonomic program. Meanwhile, perceived ease of use is the perception of workers that leads to the belief that the technology adopted does not require much effort. Workers who think that an ergonomic program can make their work easier will have the intention to get involved in its activities. However, this perception has a less significant effect compared to the previous two perceptions.

\section{Conclusion}

Workers' perceptions of perceived usefulness, perceived ease of use, and perceived trust have a significant effect on the success of the ergonomic program. However, perceived usefulness has a bigger effect than the other two perceptions. Thus it can be understood that workers tend to use technology that they believe will help them complete the job. The intensity of use and the interaction of workers with this technology indicates the ease of use. Technology that is used often, implies that the technology is more familiar and easier to use. This can serve as a guideline for the technology that the ergonomic program will introduce. 


\section{References}

Ajzen, I., \& Madden, T. J. (1986). Prediction of goal-directed behavior: Attitudes, intentions, and perceived behavioral control. Journal of Experimental Social Psychology, 22(5), 453-474. https://doi.org/10.1016/0022-1031(86)90045-4

Austin, M. J., \& Claassen, J. (2008). Impact of organizational change on organizational culture: Implications for introducing evidence-based practice. Journal of Evidence-Based Social Work, 5(1-2), 321-359. https://doi.org/10.1300/J394v05n01

Baker-Eveleth, L., \& Stone, R. W. (2015). Usability, expectation, confirmation, and continuance intentions to use electronic textbooks. Behaviour and Information Technology, 34(10), 992-1004. https://doi.org/10.1080/0144929X.2015.1039061

Bernardes, J. M., Wanderck, C., \& Moro, A. R. P. (2012). Participatory ergonomic intervention for prevention of low back pain: Assembly line redesign case. Work, 41(SUPPL.1), 5993-5998. https://doi.org/10.3233/WOR-2012-1000-5993

Burgess-Limerick, R. (2018). Participatory ergonomics: Evidence and implementation lessons. Applied Ergonomics, 68(August 2017), 289-293. https://doi.org/10.1016/j.apergo.2017.12.009

Choi, J. K., \& Ji, Y. G. (2015). Investigating the Importance of Trust on Adopting an Autonomous Vehicle. International Journal of Human-Computer Interaction, 31(10), 692-702. https://doi.org/10.1080/ 10447318.2015.1070549

Dachyar, M., \& Banjarnahor, L. (2017). Factors influencing purchase intention towards consumer-to-consumer e-commerce. Intangible Capital, 13(5), 946-966. https://doi.org/10.3926/ic.1119

Dale, A., Welch, L., \& Evanoff, B. (2018). Participatory Ergonomic Programs in Commercial Construction Projects: Engagement with Multiple Organisational Levels to Improve Effectiveness. Occup Environ Med, 75, A83-A84.

Davis, F. D. (1989). Perceived usefulness, perceived ease of use, and user acceptance of information technology. MIS Quarterly: Management Information Systems, 13(3), 319-339. https://doi.org/10.2307/249008

Davis, F. D., \& Venkatesh, V. (1996). A Critical Assessment of Potential Measurement Biases in The Technology Acceptance Model: Three Experiments. International Journal of Human Computer Studies, 45(1), 19-45. https://doi.org/10.1006/ijhc.1996.0040

De Jong, A. M., \& Vink, P. (2002). Participatory ergonomics applied in installation work. Applied Ergonomics, 33(5), 439448. https://doi.org/10.1016/S0003-6870(02)00033-9

Dixon, S. M., \& Theberge, N. (2011). Contextual factors affecting task distribution in two participatory ergonomic interventions: A qualitative study. Ergonomics, 54(11), 1005-1016. https://doi.org/10.1080/ 00140139.2011.618231

Fishbein, M., \& Ajzen, I. (1975). Belief, Attitude, Intention and Behavior: An Introduction to Theory and Research. AddisonWesley (Vol. 6). https://doi.org/10.2307/2065853

Ghazizadeh, M., Peng, Y., Lee, J. D., \& Boyle, L. N. (2012). Augmenting the Technology Acceptance Model with trust: Commercial drivers' attitudes towards monitoring and feedback. Proceedings of the Human Factors and Ergonomics Society, (October), 2286-2290. https://doi.org/10.1177/1071181312561481

Hair, J. F., Black, W. C., Babin, B. J., \& Anderson, R. E. (2014). Multivariate Data Analysis. (E. Pearson, Ed.), Pearson Education Limited (Seventh Ed, Vol. 16). London. https://doi.org/10.1111/j.1467-9574.1962.tb01184.x

Jahangiri, M., Ali, S., Najarkola, M., Gholami, T., Mohammadpour, H., Jahangiri, A., ... Jalali, M. (2015). Ergonomics Intervention to Reduce Work-Related Musculoskeletal Disorders in a Lead Mine. Health Scope, 4(4), 38-44. https://doi.org/10.17795/jhealthscope-29507

Loisel, P., Gosselin, L., Durand, P., Lemaire, J., Poitras, S., \& Abenhaim, L. (2001). Implementation of a participatory ergonomics program in the rehabilitation of workers suffering from subacute back pain. Applied Ergonomics, 32(1), 5360. https://doi.org/10.1016/S0003-6870(00)00038-7

McKnight, D. H., Choudhury, V., \& Kacmar, C. (2002). Developing and validating trust measures for e-commerce: An integrative typology. Information Systems Research, 13(3), 334-359. https://doi.org/10.1287/ isre.13.3.334.81

Muda, I., Siregar, H. S., Sembiring, S. A., Manurung, H., \& Zein, Z. (2018). Economic Value of Palm Plantation in North Sumatera and Contribution to Product Domestic Regional Bruto. In IOP Conference Series: Materials Science and Engineering (Vol. 288, No. 1, p. 012080). IOP Publishing. https://iopscience.iop.org/article/10.1088/1757899X/288/1/012080/pdf doi:10.1088/1757-899X/288/1/012080

Muda, I, F.Roosmawati, H.S Siregar, Ramli, H.Manurung \& T.Banuas. (2018). Performance Measurement Analysis of Palm Cooperative Cooperation with Using Balanced Scorecard. IOP Conference Series : Materials Science and Engineering 2017. 288.

Ministry of Industry of the Republic of Indonesia. (2015). Master Plan for National Industrial Development $2015-2035$. Master Plan for National Industrial Development 2015-2035. Jakarta: Center for Public Communication, Ministry of Industry. Retrieved from http://www.kemenperin.go.id/ripin.pdf

Muda, I, Limanto, C, Erlina (2020). An Examination of Audit Delay: Testing Several Factors of Banking Issuers as Implement Global Reporting Initiative (GRI) General Disclosures Section Reporting Practice. Quality Access to Success. 21(178). 114-121. https://www.srac.ro/calitatea/en/arhiva/2020/QAS Vol.21 No.178 Oct.2020.pdf

Muda, I; Afrina. A; E. (2019). Influence of human resources to the effect of system quality and information quality on the user satisfaction of accrual-based accounting system (Implementing of adaptive behavior assessment system theory, case in Indonesia). Contaduría y Administración, próxima publicación. 63(4), 1-25.

Purba, J. H. V. (2019). Replanting policy of Indonesian palm oil plantation in strengthening the implementation of sustainable development goals. IOP Conference Series: Earth and Environmental Science, 336(1). https://doi.org/10.1088/1755$1315 / 336 / 1 / 012012$

Ramos, F. L., Ferreira, J. B., De Freitas, A. S., \& Rodrigues, J. W. (2018). The effect of trust in the intention to use m-banking. 
Brazilian Business Review, 15(2), 175-191. https://doi.org/10.15728/bbr.2018.15.2.5

Rasmussen, C. D. N., Lindberg, N. K., Ravn, M. H., Jørgensen, M. B., Søgaard, K., \& Holtermann, A. (2017). Processes, barriers and facilitators to implementation of a participatory ergonomics program among eldercare workers. Applied Ergonomics, 58, 491-499. https://doi.org/10.1016/j.apergo.2016.08.009

Renny, Guritno, S., \& Siringoringo, H. (2013). Perceived Usefulness, Ease of Use, and Attitude Towards Online Shopping Usefulness Towards Online Airlines Ticket Purchase. Procedia - Social and Behavioral Sciences, 81, $212-216$. https://doi.org/10.1016/j.sbspro.2013.06.415

Saeed Al-Maroof, R., Alhumaid, K., \& Salloum, S. (2020). The Continuous Intention to Use E-Learning, from Two Different Perspectives. Education Sciences, 11(1), 1-20. https://doi.org/10.3390/educsci11010006

Simoneau, S., St-Vincent, M., \& Chicoine, D. (1996). Work-Related Musculoskeletal Disorders (WMSDs): A Better Understanding for More Effective Prevention. Ergonomic improvement of work: concrete cases. Retrieved from https://www.irsst.qc.ca/media/documents/PubIRSST/RG-126-ang.pdf

Skoglind-öhman, I. (2004). Assessment of Future Workshop's Usefulness as an Ergonomics Tool. International Journal OfOccupational Safety and Ergonomics (JOSE), 10(2), 119-128.

Tullar, J. M., Brewer, S., Amick, B. C., Irvin, E., Mahood, Q., Pompeii, L. A., ... Evanoff, B. (2010). Occupational safety and health interventions to reduce musculoskeletal symptoms in the health care sector. Journal of Occupational Rehabilitation, 20(2), 199-219. https://doi.org/10.1007/s10926-010-9231-y

van Eerd, D., Cole, D., Irvin, E., Mahood, Q., Keown, K., Theberge, N., ... Cullen, K. (2010). Process and implementation of participatory ergonomic interventions: A systematic review. Ergonomics, 53(10), 1153-1166. https://doi.org/10.1080/00140139.2010.513452

Venkatesh, V., \& Bala, H. (2008). Technology Acceptance Model 3 and a Research Agenda on Interventions. Journal of Decision Sciences Institute, 39(2), 273-315. https://doi.org/10.1111/j.1540-5915.2008.00192.x

Wee, C. S., Ariff, M. S., Zakuan, N., Tajudin, M. N., Ismail, K., \& Ishak, N. (2014). Consumers perception, purchase intention and actual purchase behavior of organic food products. Review of Integrative Business and Economics Research, 3(2), 378-397.

Whysall, Z. J., Haslam, R. A., \& Haslam, C. (2004). Processes, barriers, and outcomes described by ergonomics consultants in preventing work-related musculoskeletal disorders. Applied Ergonomics, 35(4), 343-351. https://doi.org/10.1016/j.apergo.2004.03.001

Zalk, D. M. (2001). Grassroots ergonomics: initiating an ergonomics program utilizing participatory techniques. The Annals of Occupational Hygiene, 45(4), 283-289. https://doi.org/10.1093/annhyg/45.4.283 
(C) 2021 by the authors; licensee Growing Science, Canada. This is an open access article distributed under the terms and conditions of the Creative Commons Attribution (CCBY) license (http://creativecommons.org/licenses/by/4.0/). 